\title{
Historical spatial range expansion and a very recent bottleneck of Cinnamomum kanehirae Hay. (Lauraceae) in Taiwan inferred from nuclear genes
}

\author{
Pei-Chun Liao1, Dai-Chang Kuo², Chia-Chia Lin³, Kuo-Chieh Ho4, Tsan-Piao Lin*2 and Shih-Ying Hwang*3
}

\begin{abstract}
Background: Species in the varied geographic topology of Taiwan underwent obvious demographic changes during glacial periods. Cinnamomum kanehirae has been exploited for timber and to obtain medicinal fungi for the past 100 years. Understanding anthropogenic factors influencing the demography of this species after the last glacial maximum (LGM) is critically important for the conservation of this species.

Results: Populations of C. kanehirae were classified into four geographic regions: northwestern (NW), west-central (WC), southwestern (SW), and southeastern (SE). In total, 113 individuals from 19 localities were sampled, and variations in the chalcone synthase gene (Chs) intron and leafy (Lfy) intron-2 sequences of nuclear DNA were examined in order to assess phylogeographic patterns, the timescales of demographic and evolutionary events, and recent anthropogenic effects. In total, 210 Chs and 170 Lfy sequences, which respectively constituted 36 and 35 haplotypes, were used for the analyses. Estimates of the migration rate $(M)$ through time revealed a pattern of frequent gene flow during previous and the present interglacials. The isolation-by-distance test showed that there generally was no significant correlation between genetic and geographic distances. The level of among-region genetic differentiation was significant when comparing eastern to western populations. However, no significant among-region genetic differentiation was found in comparisons among the four geographic regions. Moreover, essentially no genetic structuring was found for the three regions west of the CMR. A fit of spatial range expansion was found for pooled and regional samples according to the non-significant values of the sum of squared deviations. Using the Bayesian skyline plot (BSP) method, a recent bottleneck after the LGM expansion was detected in both regional and pooled samples.

Conclusions: Common haplotype distributions among geographic regions and the relatively shallow genetic structuring displayed are the result of historical gene flows. Southward dispersals in an earlier time frame from the NW region and in a later time frame from the SE region were inferred. The BSP analysis suggested a postglacial expansion event. Recent trends, however, refer to a bottleneck due to human interventions observed for both pooled and regional C. kanehirae samples.
\end{abstract}

\section{Background}

Climate change is an important factor influencing organisms' evolutionary history, especially their demographic dynamics [1]. The Pleistocene was an era of temperature oscillations due to cyclic glacial/interglacial events since 0.9 million years ago (Mya) [2]. Many species experienced

*Correspondence: tpl@ntu.edu.tw, hsy9347@ntnu.edu.tw

2 Institute of Plant Biology, National Taiwan University, Taipei 10617, Taiwan 3 Department of Life Science, National Taiwan Normal University, Taipei, 11677, Taiwan

Full list of author information is available at the end of the article huge bottleneck events during glacial periods because their growth under the prevailing unpleasant cold and dry conditions was restricted to refugia [1,2]. Contraction into refugia was reported for both animals [3-5] and plants [6-8]. Although glacial events occur on a global scale, the lowlands of southeastern Asia were not covered with ice but were drier and colder. Thus, the climatic changes were cyclic pluvial and interpluvial in Asia (respectively corresponding to interglacial and glacial periods) during the Pleistocene. According to Hewitt's [2] speculation on the climate of tropical mountains according to several faunal studies, stable moist habitats in areas 
not covered by ice provided suitable refugia for species survival and the generation of new lineages. Glacials changed climates in Asia and several refugia of different species are consistently being found [9-12], which shows that climate changes in the Pleistocene indeed affected the demographic history of Asian species.

Taiwan is a continental island situated off the coast of southern East Asia. The Central Mountain Ridge (CMR) is a continuous ridge trending north-south and divides Taiwan into eastern and western geographic areas [13]. There are more than 200 peaks exceeding $3000 \mathrm{~m}$ in elevation in the CMR. The varied geographical topologies of Taiwan allowed habitats and lineages to persist through altitudinal shifts during glacial/interglacial cycles [cf. [2]]. The remnants of glaciations at the top of some peaks indicate the former occurrence of glaciers [14,15]. The floristic composition of Taiwan is characterized by high levels of endemism (40\%) and species diversity [16]. Forests in middle to low elevations of Taiwan consist of evergreen broadleaf trees, including camphor (Cinnamomum spp.), banyan (Ficus spp.), beech (Fagus spp.), etc. During glacial periods, conifers which were distributed at high elevations in Taiwan spread to lower elevations to escape the ice-covered mountaintops $[14,17,18]$, and those species originally distributed in middle and low elevations slowly migrated to the lowlands. However, the dry environments of the lowlands during glacial periods may have restricted the distributions of broadleaf trees and resulted in bottleneck effects. Following glacial periods, climates of interglacial periods were warm and moist in Taiwan, and populations would have recovered and expanded. Climate-dependent changes in demographics of trees in Taiwan are evidenced by the pollen record [19] and genetics, e.g., Michelia formosana (Magnoliaceae) [20], Cunninghamia konishii (Cupressaceae) [21], and Quercus (or Cyclobalanopsis) glauca (Fagaceae) [22].

In this study, we chose Cinnamomum kanehirae Hayata (Lauraceae) as an example to explore the influence of the evolutionary history of middle-elevation broadleaf trees. Cinnamomum kanehirae belongs to the Cinnamomum group of the Cinnamomeae sensu Kostermans. The Cinnamomum group shows an amphi-Pacific disjunct distribution with its sister group, the Persea group, the disruption of boreotropical ranges of which is attributed to Eocene-Oligocene climatic cooling. The genus Cinnamomum is considered to have originated about $35 \pm 6$ or $138 \pm 19$ Mya by estimates of the relaxed molecular clock using outgroups with two different divergence times [23]. The genus Cinnamomum comprises approximate 250 species distributed in tropical and subtropical eastern Asia, Australia, and the Pacific islands, and 8 of 14 Cinnamomum species in Taiwan are endemic, including $C$. kanehirae. Cinnamomum kanehirae is distributed at 200 2000 $\mathrm{m}$ in elevation, and is mixed with C. micran- thum in broadleaf forests throughout the island [24]. Cinnamomum kanehirae has a long lifespan, was abundant at the beginning of the 20th century and is one of the most valuable timber species in Taiwan [25]. The range distribution of $C$. kanehirae is contiguous throughout Taiwan except the northeastern part east of the CMR $[25,26]$ (Figure 1). A fungus called Antrodia cinnamomea Chang \& Chou, parasitic inside the C. kanehirae trunk [27-29], is valued as a medicine due to its antioxidant [30-32], anticancer [33], antiviral [34], and antibiotic properties [33]. In total, 46,000 trees consisting of live, dead, and root stumps were recorded during an extensive survey of all areas, with the exception of most of the southeastern part of Taiwan between 1918 and 1922 [26], but it is now extremely difficult to find a standing live tree in the wild due to the intensive logging during 1920 1970 especially

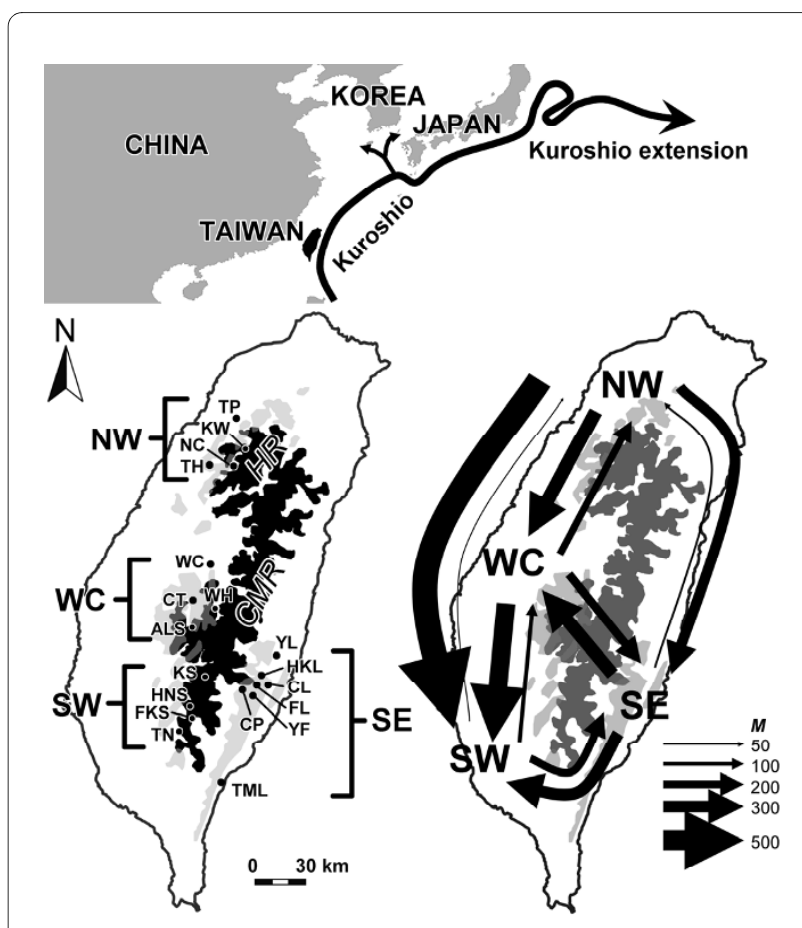

Figure 1 Geographical distribution and magnitudes of migration routes of Cinnamomum kanehirae. In the upper panel, the flow of the Kuroshio Current is shown. In the bottom left panel, four geographic regions defined by Lin et al. [35] together with the location of populations are indicated. The northwestern region (NW) contains populations TP, KW, TH, and NC; the west-central region (WC) contains populations WC, CT, WH, and ALS; the southwestern region (SW) contains populations $\mathrm{KS}, \mathrm{HNS}, \mathrm{FKS}$, and $\mathrm{TN}$; and the southeastern region (SE) contains populations FL, HKL, CL, YL, CP, YF, and TML. Abbreviations of population codes are listed in Table 1. The dark area indicates elevations above $2000 \mathrm{~m}$, and the gray area indicates the distribution range of C. kanehirae outside the area above $2000 \mathrm{~m}[26,35]$. HR, Huseshan Range; CMR, Central Mountain Ridge. In the bottom right panel, directions and magnitudes of gene flow estimated by the Bayesian approach are shown. Arrows indicate the direction of migration and the thickness of the arrows indicates values of the migration parameter $(M)$ calculated by the computer software, MIGRATE 3.0 [54]. 
of populations of the northwestern and southwestern regions as well as selective cutting to obtain the medicinal fungus in recent years.

According to an allozyme survey, C. kanehirae has a relatively higher genetic diversity in terms of heterozygosity and other parameters compared to those of other local tree species [35]. DNA is a more-sensitive genetic marker, and is very useful for studying the demographic history and/or migratory footprints of species. Phylogeographic studies of several species in Taiwan consistently point to a rapid postglacial expansion event. The suggestion of population expansion of most of those studies was based on the "star-like" phylogeny of chloroplast DNA (cpDNA) haplotypes due to the high frequencies of singletons [21,36,37]. Approaches based on the coalescence theory are used to trace the evolutionary history, e.g., the Bayesian skyline plot (BSP) analysis [38]. Plastid DNA is commonly used for making phylogeographic inferences; however, a strong selective sweep acting across the entire plastid genome can reduce the genetic variation of plastid DNA [cf. [39]]. The genetic variation of C. kanehirae estimated from cpDNA is very low (only six haplotypes in populations and $\pi=0.00016 \pm 0.00007$ ) [40], and the amounts of variation cannot reflect the long-term demographic history or the historical effective population size. Nuclear DNA is a suitable marker to obtain more information so that the evolutionary history of C. kanehirae can be traced in Taiwan.

In this study, the intron of chalcone synthase $(C h s)$ and the second intron of the Leafy gene (Lfy) of nuclear DNA were sequenced to assess the phylogeographic structure of C. kanehirae in Taiwan. Population genetic analyses of C. kanehirae should provide more insights into geographic influences on migratory events (historical gene flow and recent dispersal). Furthermore, a coherent timescale for the geologic time and demographic events as well as climate change was established using the coalescent-based Bayesian framework. The ancestral effective population size of C. kanehirae was estimated in order to understand the trend of historical demography. Such a study is vital to our understanding of the process of demographic changes corresponding to how climate changes affected subtropical tree species in the Pleistocene.

\section{Methods}

\section{Plant materials and DNA amplification}

In total, 113 individuals originating from 19 populations of C. kanehirae of Taiwan were collected from a scion garden at the Liukuei Research Center, Taiwan Forestry Research Institute (TFRI), southwestern Taiwan (Table 1, Figure 1). This scion garden was set up in 1995 to house intraspecific variations of C. kanehirae. Sample sizes of each population range from 3 to 16 individuals. Young developed leaves were collected from this garden, preserved on silica gel, and carried back to the laboratory for DNA extraction. Total DNA was extracted from groundup leaf powder according to a modified cetyltrimethyl ammonium bromide (CTAB) procedure [41]. DNA was precipitated with ethanol and after washing with 70\% ethanol, was dissolved in $200 \mu \mathrm{L}$ TE buffer ( $\mathrm{pH}$ 8.0) and stored at $-20^{\circ} \mathrm{C}$. The DNA concentration was determined for each sample using the GeneQuant II RNA/DNA Calculator (Amersham Biosciences, Taipei, Taiwan).

\section{Primers, polymerase chain reaction (PCR), and sequencing}

PCRs were performed with universal primers for the Chs first intron (CHSx1F and CHSx2RN) [42] and the Lfy second intron (Mk.LFY-1n and Mk.LFY-2n) [43]. Amplifications were performed in a DNA programmable thermal cycler (PTC-100, MJ Research, Watertown, MA, USA) under the following protocol: initial denaturation at $94^{\circ} \mathrm{C}$ for $2 \mathrm{~min}$ followed by 35 cycles of $30 \mathrm{~s}$ at $94^{\circ} \mathrm{C}, 30 \mathrm{~s}$ of annealing at 52 or $48^{\circ} \mathrm{C}$ (Chs and $L f y$, respectively), and 2 min at $72^{\circ} \mathrm{C}$, followed by a subsequent 7 -min final extension at $72^{\circ} \mathrm{C}$. The PCR mixture $(50 \mu \mathrm{L})$ contained $50 \mathrm{mM}$ $\mathrm{KCl}, 1.5 \mathrm{mM} \mathrm{MgCl}_{2}, 0.001 \%$ gelatin, $10 \mathrm{mM}$ Tris- $\mathrm{HCl}(\mathrm{pH}$ 8.3), $100 \mu \mathrm{M}$ dNTPs, $0.2 \mu \mathrm{M}$ of the primer, $20 \mathrm{ng}$ of template DNA, $1 \mu \mathrm{g}$ RNase, and $0.5 \mathrm{U}$ Taq polymerase (Amersham Biosciences). Amplification products were run on $1 \%$ agarose gels, purified with a QiaGen purification kit (Taipei, Taiwan), and sequenced using both forward and reverse reactions with a Taq BigDye Terminator Cycle Sequencing Kit and a model ABI373A automated sequencer (Applied Biosystems, Foster City, CA, USA). This was applied to sequences of homozygotes or sequences containing one polymorphic site. Heterozygotes were visualized as "double peaks" at polymorphic sites in the chromatogram. The identity of the two haplotypes within a heterozygote was inferred through haplotype subtraction [44], which deduces haplotypes by a comparison of heterozygote sequences to haplotypes commonly observed in the global sample. When the chromatogram quality did not permit this procedure, PCR products were cloned using a yT\&A vector (Yeastern Biotech, Taipei, Taiwan) according to the manufacturer's protocol. Three clones were sequenced for each individual when sequences contained two or more polymorphic sites and/or an unpaired indel (an indel of a different length). The two sequences of a heterozygote were separated by comparing sequences of the PCR product and cloned sequence. Fortunately, no sequence containing more than one indel was found in the length of Chs and Lfy used in this study. Because the Taq polymerase error was estimated to be as high as $0.1 \%$ [45] or even higher, sequences containing only one polymorphic site were considered to be produced by a Taq error and were excluded from the analysis. All haplotype sequences were 
Table 1: Sampling sites, population codes, region to which a population belongs, longitude and latitude of populations, and haplotypes in each population of Cinnamomum kanehirae in Taiwan.

\begin{tabular}{|c|c|c|c|c|c|c|c|}
\hline Population & Code & Geographic regions & Elevation $(\mathbf{m})$ & Longitude & Latitude & Chs Haplotypes & Lfy Haplotypes \\
\hline Kuanwu & KW & Northwestern (NW) & 1500 & $121^{\circ} 07^{\prime} 12^{\prime \prime} \mathrm{E}$ & $24^{\circ} 30^{\prime} 36^{\prime \prime} \mathrm{N}$ & $4(3), 5(2), 22(1)$ & $1(2), 11(1), 14(1), 26(2)$ \\
\hline Nanchuang & NC & Northwestern (NW) & 1100 & $121^{\circ} 03^{\prime} 00^{\prime \prime} \mathrm{E}$ & $24^{\circ} 24^{\prime} 36^{\prime \prime} \mathrm{N}$ & $3(1), 4(3), 13(1), 14(12), 15(2), 24(1)$ & $1(10), 11(1), 14(1)$ \\
\hline Tahu & $\mathrm{TH}$ & Northwestern (NW) & 1400 & $120^{\circ} 52^{\prime} 12^{\prime \prime} \mathrm{E}$ & $24^{\circ} 25^{\prime} 12^{\prime \prime} \mathrm{N}$ & $4(1), 15(1), 22(3), \underline{31}(1)$ & $1(4), 11(2), 14(2)$ \\
\hline Taping & $\mathrm{TP}$ & Northwestern (NW) & 1300 & $121^{\circ} 03^{\prime} 36^{\prime \prime} \mathrm{E}$ & $24^{\circ} 40^{\prime} 48^{\prime \prime} \mathrm{N}$ & $2-3(1), 4(3), 15(2), \underline{34}(3)$ & $1(2), 3(2), 26(2), \underline{33}(1)$ \\
\hline Alishan & ALS & West-central (WC) & 2000 & $120^{\circ} 47^{\prime} 24^{\prime \prime} \mathrm{E}$ & $23^{\circ} 30^{\prime} 36 " \mathrm{~N}$ & $1-2(2), 3(1), 4(3), 5(1), \underline{6}(1)$ & $1(2), 2(2)$ \\
\hline Chitou & $\mathrm{CT}$ & West-central (WC) & 1500 & $120^{\circ} 47^{\prime} 24^{\prime \prime} \mathrm{E}$ & $23^{\circ} 39^{\prime} 36^{\prime \prime} \mathrm{N}$ & $\begin{array}{l}\text { 1(3), 3(1), 4(7), 5(2), 9(1), 12(1), 13(1), 14(4), } \\
\text { 15(3), 16(1), } \underline{17}(1), \underline{18}(1), \underline{19}(1), \underline{20}(2), \underline{21}(1)\end{array}$ & $11(1), 12(2)$ \\
\hline Wuchieh & WC & West-central (WC) & 600 & $120^{\circ} 54^{\prime} 36^{\prime \prime} \mathrm{E}$ & $23^{\circ} 51^{\prime} 36^{\prime \prime} \mathrm{N}$ & $3(2), 4(2), 30(1)$ & $12(1), 17(1), \underline{34}(1), \underline{35}(1)$ \\
\hline Wanghsiang & WH & West-central (WC) & 1100 & $120^{\circ} 55^{\prime} 48^{\prime \prime} \mathrm{E}$ & $23^{\circ} 37^{\prime} 12^{\prime \prime} \mathrm{N}$ & $3(2), 15(1), 16(1), \underline{35}(1)$ & $25(1), 26(5)$ \\
\hline Fengkangshan & FKS & Southwestern (SW) & 2100 & $120^{\circ} 47^{\prime} 24^{\prime \prime} \mathrm{E}$ & $23^{\circ} 00^{\prime} 00^{\prime \prime} \mathrm{N}$ & $\begin{array}{l}1(11), 2(1), 4(4), 9(1), 22(1), 23(2), 24(1), \\
\underline{25}(1)\end{array}$ & $1(14), 11(2), \underline{13}(1), 14(2)$ \\
\hline Hsinanshan & HNS & Southwestern (SW) & 1000 & $120^{\circ} 46^{\prime} 48^{\prime \prime} \mathrm{E}$ & $23^{\circ} 03^{\prime} 36^{\prime \prime} \mathrm{N}$ & $4(1), 5(1), 15(1), \underline{27}(1), \underline{28}(1)$ & $11(4), 22(4)$ \\
\hline Kuanshan & KS & Southwestern (SW) & 1000 & $120^{\circ} 54^{\prime} 36^{\prime \prime} \mathrm{E}$ & $23^{\circ} 24^{\prime} 36^{\prime \prime} \mathrm{N}$ & $3(4), 4(8), 8(2), 9(5), \underline{29}(1), 30(1)$ & $\begin{array}{l}\text { 1(1), 2(1), 12(2), 17(4), 22(1), 23 }(1), \underline{24}(1), 25(1), \\
26(3), \underline{27}(1), \underline{28}(4)\end{array}$ \\
\hline Tona & $\mathrm{TN}$ & Southwestern (SW) & 1500 & $120^{\circ} 43^{\prime} 12^{\prime \prime E}$ & $22^{\circ} 54^{\prime} 36 " \mathrm{~N}$ & $4(1), 15(3), 20(1), \underline{33}(2)$ & $22(2), \underline{32}(1)$ \\
\hline Chulu & $\mathrm{CL}$ & Southeastern (SE) & 200 & $121^{\circ} 18^{\prime} 00^{\prime \prime} \mathrm{E}$ & $23^{\circ} 21^{\prime} 00^{\prime \prime} \mathrm{N}$ & $3(3), 4(2), 7(1)$ & $3(2), 4(1), 5(3)$ \\
\hline Chingping & $\mathrm{CP}$ & Southeastern (SE) & 1200 & $121^{\circ} 10^{\prime} 12^{\prime \prime} \mathrm{E}$ & $23^{\circ} 40^{\prime} 48^{\prime \prime} \mathrm{N}$ & $3(1), 4(12), 8(1), 9(1), 11(1)$ & $3(3), 4(1), 5(4), \underline{6}(1), \underline{z}(1), \underline{8}(1), \underline{9}(1), \underline{10}(1)$ \\
\hline Fuli & $\mathrm{FL}$ & Southeastern (SE) & 600 & $121^{\circ} 11^{\prime} 24^{\prime \prime} \mathrm{E}$ & $23^{\circ} 10^{\prime} 48^{\prime \prime} \mathrm{N}$ & $3(2), 4(2), 11(1), 15(1)$ & $1(2), 3(1), \underline{15}(1), \underline{16}(1)$ \\
\hline Hsiukuluan & HKL & Southeastern (SE) & 700 & $121^{\circ} 13^{\prime} 12^{\prime \prime} \mathrm{E}$ & $23^{\circ} 15^{\prime} 00^{\prime \prime} \mathrm{N}$ & $3(7), 4(6), 8(1), 9(1), \underline{26}(1)$ & $3(8), 12(5), 17(1), \underline{18}(2), 19(2), \underline{20}(1), \underline{21}(1)$ \\
\hline Taimali & TML & Southeastern (SE) & 600 & $121^{\circ} 00^{\prime} 00^{\prime \prime} \mathrm{E}$ & $22^{\circ} 30^{\prime} 36^{\prime \prime} \mathrm{N}$ & $3(3), 4(4), 9(2), \underline{32}(1)$ & $19(2), \underline{29}(4), \underline{30}(1), \underline{31}(1)$ \\
\hline Yungfeng & YF & Southeastern (SE) & 600 & $121^{\circ} 10^{\prime} 12^{\prime \prime} \mathrm{E}$ & $23^{\circ} 04^{\prime} 12^{\prime \prime} \mathrm{N}$ & $3(4), 4(4), 14(1), \underline{36}(1)$ & $1(8)$ \\
\hline Yuli & $\mathrm{YL}$ & Southeastern (SE) & 1000 & $121^{\circ} 15^{\prime} 00^{\prime \prime} \mathrm{E}$ & $23^{\circ} 11^{\prime} 24^{\prime \prime} \mathrm{N}$ & $3(2), 4(4), 9(2)$ & $3(1), 11(2), 12(7)$ \\
\hline
\end{tabular}

The numbers in parentheses indicates the frequency of a haplotype at a particular site. Haplotypes which are population-specific are also region-specific, and they are underlined. 
deposited in the NCBI nucleotide sequence database under the following accession numbers: FJ858218 FJ858253 (Chs) and GQ260573 GQ260607 (Lfy).

\section{DNA sequence analyses}

Sequence alignments were performed with Clustal X [46] and manually edited using BioEdit vers. 7.0.9 [47]. After sequence alignment, indels were treated as the fifth character when calculating the indices of genetic diversity. The nucleotide diversity $(\pi)$, haplotype diversity $(H d)$, and $\theta$ estimated by segregating sites $(S)$ were calculated using DnaSP vers. 5.0 [48].

\section{Population structure}

Populations of C. kanehirae were formerly classified into four geographic regions, northwestern (NW), west-central (WC), southwestern (SW), and southeastern (SE), according to their geographic distributions (Figure 1) [35]. In addition, the CMR is considered to be a barrier to gene flow, and the structures of populations distributed in eastern and western Taiwan were also examined. The haplotype network was reconstructed with the algorithm of statistical parsimony using TCS vers. 1.21 [49]. The long-fragment indel of Chs sequences was treated as a one-mutation step and recoded. An analysis of molecular variance (AMOVA) was performed with Arlequin vers. 3.11 [50] in order to examine the components of genetic variation and the population structure.

Genetic differentiation between populations (pairwise $F_{\mathrm{ST}}$ ) was calculated by Arlequin [50] based on Wright's [51] equation. To examine the influence of geographic barriers on levels of gene flow, the isolation-by-distance (IBD) model was used. If the stepping-stone dispersal model was tenable for $C$. kanehirae (and then the reinforcement of the geographic distance was necessary when estimating using MIGRATE), the IBD pattern was assumed. The IBD model was examined by the Mantel test $\left(F_{\mathrm{ST}}\right.$ vs. geographic or altitudinal slope distance) to analyze the geographic effect on the genetic distribution. A reduced major axis (RMA) regression [52] was used to calculate the slope for the IBD test. Hellberg [52] indicated that the RAM regression is superior to the ordinary least squares regression for the IBD test based on simulation data. The IBD test considering both linear geographic distance and altitudinal slope was performed with the web-based computer program, IBDWS vers. 3.15 [53] (available at http://ibdws.sdsu.edu/ ibdws/).

\section{Intralocus recombination}

In the following analyses, all sites within studied loci were assumed to share the same genealogical history. However, recombination is believed to be common in nuclear loci and to influence the outcome of genealogically based analyses [54]. Therefore, we assessed recombination events with the "four-gamete test" using DnaSP vers. 5.0 [48]. Although this test only evaluates the minimum number of intralocus recombination events, it is sensitive to the presence of recombinations. When the test of the dataset of each locus (Chs and $L f y$ ) suggested an intralocus recombination, we discarded the sites within the recombination block and retained the longest possible contiguous unrecombined sequence for subsequent analyses.

\section{Migration rate through time}

Because the incomplete migration-drift equilibrium was inferred based on the IBD results, the gene flow $(\mathrm{Nm})$ estimated by the reciprocal of pairwise $F_{\mathrm{ST}}$ by Wright's [51] equation under the assumption of the migrationdrift equilibrium may have been incorrect. Hence, varying degrees of the migration rate through time had to be considered. We jointly estimated all immigration and emigration rates by the Metropolis-coupled Markov chain Monte Carlo (MCMCMC) strategy in the MIGRATE program vers. 3.0 [55]. Because the Mantel test revealed essentially no correlations between genetic and geographic distances (see "Results"), the assumption of an identical migration potential was adopted in the MIGRATE algorithm. The prior distributions of uniform $\theta$ and equal migration rates were incorporated into the Bayesian approach in the MIGRATE algorithm. $F_{\mathrm{ST}}$ estimates were used as starting values for the initial analysis. For all other analyses, parameters at the end of the previous run were used as starting values for the next run until results converged at approximately the same values. We used settings of three long chains with $5 \times 10^{6}$ sampled and $5 \times 10^{3}$ recorded genealogies and discarded $25 \%$ of them at the beginning of a chain. Multiple long chains were combined for estimates. Adaptive heating was applied with temperature specifications of 1.0, 1.2, 1.5, and 3.0. Three replicates of the dataset were analyzed to calculate the average and confidence intervals. Because gene flow between populations estimated by pairwise $M$, which indicates the migration rate over the mutation rate, revealed confusing results (data not shown), four geographic regions based on the determination of Lin et al. [35] were used for the reanalysis.

\section{Inferring the historical demography}

Signatures of population demographic changes (bottlenecks or expansions) in C. kanehirae were first examined by Tajima's $D$ [56] and Fu's Fs [57] statistics using DnaSP 5.0 [48] to see whether C. kanehirae data conformed to expectations of neutrality or departed from neutrality due to factors such as a population bottleneck or expansion. The examination of deviation from neutrality by both $D$ and $F$ s indices was based on 1000 coalescent simulations with consideration of the recombination rate 
using DnaSP. Expectations of these statistics are nearly zero in a constant-size population; significant negative values indicate a sudden expansion in population size, whereas significant positive values indicate processes such as a population subdivision or recent population bottlenecks. Second, demographic changes in C. kanehirae were also examined by calculating the raggedness index of the observed mismatch distribution for each of the populations according to the population expansion model implemented in Arlequin 3.1 [50]. This measure quantifies the smoothness of the observed mismatch distribution. Small raggedness values represent a population which has experienced sudden expansion whereas higher values of the raggedness index suggest stationary or bottlenecked populations $[58,59]$. Third, the demographic history of whether $C$. kanehirae underwent a range expansion was investigated by the spatial expansion model in Arlequin [50,60-62]. We employed parametric bootstrapping (1000 replicates) as implemented in Arlequin to test the goodness-of-fit of the observed mismatch distribution to that expected under the spatial expansion model using the sum of squared deviations (SSD) statistic for regional and pooled samples. A significant SSD value is taken as evidence of departure from the estimated demographic model of spatial expansion in subdivided populations [60,62] using Arlequin [50]. The model of spatial expansion assumes that subdivided populations expanded their distribution range and increased the total number of individuals $[60,61]$. It estimates tau $(\tau)$, the demographic expansion factor, with 95\% confidence intervals, and the mutation parameter, $\theta$, as well as the number of migrants $(M)$. This least-squares estimation of $\tau$ is reliable but was found to be unreliable for estimating the migration parameter, $M$ [63]. Therefore, we took the $M$ estimate of $>1$ together with a non-significant SSD value as evidence of spatial expansion. The time at which the expansion event took place was dated following the expression, $t=\tau / 2 \mu \mathrm{k}$, where $\tau$ is the estimated number of generations since the expansion, $\mu$ is the mutation rate per site per generation, and $\mathrm{k}$ is the sequence length. A mutation rate of $1.5 \%$ per $10^{6}$ years per site was used for both Chs [64] and Lfy. We assumed a mean generation time of 20 years for C. kanehirae in converting the time to expansion to years.

Patterns of historical demography can also be inferred from estimates of the effective population size over time using the BSP method [38] as implemented in BEAST vers. 1.4.8 [65] for estimating fluctuations in the effective population size. This method estimates a posterior distribution of effective population sizes through time via MCMC procedures, by moving backward until the time of the most recent common ancestor is reached. The constant population size coalescent model was the basic assumption used for this approach. A HKY model together with among-site rate heterogeneity across all branches but assuming a strict molecular clock was used for this calculation. Markov chains were run for $2.5 \times 10^{7}$ generations and were sampled every 1000 generations, with the first 2500 samples discarded as burn-in. Three replicates were run and combined to separately analyze the Chs and Lfy datasets. Other parameters were set as default values. TRACER vers. 1.4 [66] was used to visualize the posterior probabilities of the Markov chain statistics and to calculate a statistical summary of the genetic parameters.

\section{Results}

\section{Genetic diversity}

In total, 82 of 113 samples of Chs (72.5\%) and 41 of 94 samples of $L f y(43.6 \%)$ were heterozygotes. Although all 226 alleles of Chs and 188 alleles of $L f y$ were unambiguously identified, 16 and 18 of them, respectively, were probably derived from Taq errors and were thus excluded from further analysis. PCR amplification resulted in 637 and $657 \mathrm{bp}$ of the Chs gene sequence spanning exon 1 (1 18 bp), intron 1 (19 594 bp or a 20-bp indel), and exon 2 (595 637 bp), and $741 \mathrm{bp}$ of the $L f y$ gene sequence spanning exon 2 (1 75 bp), intron 2 (76 692 bp), and exon 3 (693 741 bp). All Chs variations occurred within the region of the intron. In aligned $L f y$ sequences, two variable sites were found within exon 2, 29 variable sites were found within intron 2 , and three variable sites were found within exon 3 (Additional file 1). The aligned lengths of $210 \mathrm{Chs}$ sequences were $657 \mathrm{bp}$ and $170 \mathrm{Lfy}$ sequences were $741 \mathrm{bp}$, which yielded 36 and 35 haplotypes, respectively (Table 1 , Additional file 1). Details of the genetic diversity of populations and regions are presented in Table 2. Among 34 polymorphic sites of Chs, 14 were substitutions and 20 were indels; whereas only one indel was found among 35 polymorphic sites of Lfy. Among all of the populations examined, nucleotide diversity $(\pi)$ was 0.00716 and ranged from 0.00372 (population $\mathrm{CP}$ in the SE region) to 0.00865 (population ALS in the WC region) in Chs and was 0.00479 and ranged from 0 (population YF in the SE region) to 0.00838 (population FL in the SE region) in $L f y$. Haplotype diversity $(H d)$ was 0.841 and ranged from 0.515 (population $\mathrm{CP}$ in the SE region) to 1.000 (population $\mathrm{HNS}$ in the SW region) in Chs and was 0.895 and ranged from 0.000 (population YF in the SE region) to 1.000 (population WC in the WC region) in Lfy. Haplotype and nucleotide diversities of the four geographic regions were also calculated: haplotype diversities $(H d)$ ranged from 0.679 (SE region) to 0.906 (WC region) in Chs and from 0.674 (NW region) to 0.896 (SE region) in $L f y$; nucleotide diversities ranged from 0.00511 (SE region) to 0.00784 (SW region) in Chs and from 0.00260 (WC region) to 0.00625 (SE region) in $L f y$. When comparing the genetic diversity of regions to each 
Table 2: Genetic diversity of 19 populations of Cinnamomum kanehirae estimated using Chs and Lfy sequences.

\begin{tabular}{|c|c|c|c|c|c|c|c|c|}
\hline & \multicolumn{8}{|c|}{ Chs } \\
\hline & $N$ & $H$ & $H d$ & $\pi(\times 10-3)$ & $\theta(S)(\times 10-3)$ & Tajima's $D(P)$ & Fu's Fs $(P)$ & Raggedness index \\
\hline \multicolumn{9}{|c|}{ Population } \\
\hline KW & 6 & 3 & $0.733 \pm 0.155$ & $6.91 \pm 1.88$ & $6.19 \pm 3.42$ & $-0.027(0.757)$ & $0.094(0.944)$ & 0.5067 \\
\hline NC & 10 & 8 & $0.889 \pm 0.075$ & $7.50 \pm 1.33$ & $6.66 \pm 3.20$ & $-0.018(0.788)$ & $-0.731(0.725)$ & 0.0844 \\
\hline TH & 6 & 4 & $0.800 \pm 0.172$ & $6.49 \pm 2.84$ & $7.56 \pm 4.07$ & $-0.112(0.274)$ & $0.450(0.633)$ & 0.6267 \\
\hline TP & 10 & 5 & $0.844 \pm 0.080$ & $7.33 \pm 0.93$ & $5.55 \pm 2.75$ & $-0.022(0.974)$ & $-0.665(0.886)$ & 0.1368 \\
\hline ALS & 10 & 6 & $0.844 \pm 0.080$ & $8.65 \pm 1.08$ & $6.66 \pm 3.20$ & $-0.296(0.976)$ & $-0.551(0.937)$ & 0.0756 \\
\hline CT & 30 & 17 & $0.917 \pm 0.030$ & $7.20 \pm 0.40$ & $4.76 \pm 1.95$ & $-0.033(0.994)$ & $-2.684(0.406)$ & 0.0256 \\
\hline WC & 5 & 4 & $0.800 \pm 0.164$ & $5.65 \pm 1.45$ & $4.52 \pm 2.76$ & $-0.041(0.987)$ & $0.061(0.869)$ & 0.2800 \\
\hline WH & 5 & 4 & $0.900 \pm 0.161$ & $7.85 \pm 2.20$ & $8.29 \pm 4.66$ & $0.011(0.314)$ & $-0.369(0.760)$ & 0.3100 \\
\hline FKS & 22 & 8 & $0.732 \pm 0.090$ & $8.09 \pm 0.98$ & $5.60 \pm 2.35$ & $-0.089(0.969)$ & $-0.486(0.803)$ & 0.1135 \\
\hline HNS & 5 & 6 & $1.000 \pm 0.126$ & $7.22 \pm 2.51$ & $8.29 \pm 4.66$ & $-0.043(0.149)$ & $0.166(0.104)$ & 0.1600 \\
\hline KS & 21 & 7 & $0.786 \pm 0.058$ & $4.96 \pm 0.33$ & $3.05 \pm 1.49$ & $-0.053(0.993)$ & $-1.000(0.903)$ & 0.0986 \\
\hline TN & 7 & 5 & $0.524 \pm 0.209$ & $3.89 \pm 2.33$ & $5.13 \pm 2.80$ & $-0.066(0.119)$ & $0.357(0.843)$ & 0.1950 \\
\hline $\mathrm{CL}$ & 6 & 5 & $0.733 \pm 0.155$ & $5.23 \pm 1.27$ & $4.13 \pm 2.44$ & $0.022(0.970)$ & $-0.082(0.933)$ & 0.5067 \\
\hline $\mathrm{CP}$ & 17 & 7 & $0.515 \pm 0.145$ & $3.72 \pm 1.09$ & $3.71 \pm 1.79$ & $-0.035(0.541)$ & $0.105(0.509)$ & 0.3279 \\
\hline $\mathrm{FL}$ & 6 & 4 & $0.867 \pm 0.129$ & $7.64 \pm 1.53$ & $6.88 \pm 3.75$ & $0.010(0.833)$ & $-0.451(0.878)$ & 0.2756 \\
\hline HKL & 16 & 5 & $0.650 \pm 0.075$ & $5.14 \pm 0.46$ & $3.31 \pm 1.66$ & $-0.062(0.989)$ & $-0.281(0.961)$ & $0.3197^{*}$ \\
\hline TML & 10 & 4 & $0.778 \pm 0.091$ & $5.65 \pm 0.85$ & $4.44 \pm 2.29$ & $-0.041(0.923)$ & $-0.335(0.931)$ & 0.1590 \\
\hline YF & 10 & 4 & $0.733 \pm 0.101$ & $5.44 \pm 0.64$ & $3.88 \pm 2.06$ & $-0.011(0.984)$ & $-0.553(0.940)$ & 0.2696 \\
\hline YL & 8 & 3 & $0.714 \pm 0.123$ & $5.16 \pm 0.82$ & $3.63 \pm 2.05$ & $-0.023(0.995)$ & $-0.115(0.958)$ & 0.2041 \\
\hline \multicolumn{9}{|c|}{ Region } \\
\hline NW & 32 & 10 & $0.853 \pm 0.039$ & $7.35 \pm 0.57$ & $5.46 \pm 2.15$ & $-0.022(0.919)$ & $-1.308(0.771)$ & 0.0332 \\
\hline WC & 50 & 20 & $0.906 \pm 0.024$ & $7.55 \pm 0.31$ & $4.56 \pm 1.74$ & $-0.048(0.994)$ & $-3.671(0.583)$ & 0.0114 \\
\hline SW & 55 & 20 & $0.876 \pm 0.026$ & $7.84 \pm 0.29$ & $4.46 \pm 1.69$ & $-0.014(0.999)$ & $-3.388(0.643)$ & 0.0251 \\
\hline SE & 73 & 14 & $0.679 \pm 0.041$ & $5.11 \pm 0.21$ & $3.23 \pm 1.28$ & $-0.034(0.953)$ & $-1.019(0.676)$ & 0.2150 \\
\hline Total & 210 & 41 & $0.841 \pm 0.019$ & $7.16 \pm 0.19$ & $3.71 \pm 1.25$ & $-0.064(0.999)$ & $-4.405(0.255)$ & 0.0186 \\
\hline
\end{tabular}


Table 2: Genetic diversity of 19 populations of Cinnamomum kanehirae estimated using Chs and Lfy sequences. (Continued)

\begin{tabular}{|c|c|c|c|c|c|c|c|c|}
\hline & \multicolumn{8}{|c|}{ Lfy } \\
\hline & $N$ & $H$ & $H d$ & $\pi(\times 10-3)$ & $\theta(S)(\times 10-3)$ & Tajima's $D(P)$ & Fu's Fs $(P)$ & Raggedness index \\
\hline \multicolumn{9}{|c|}{ Population } \\
\hline KW & 6 & 4 & $0.867 \pm 0.129$ & $1.89 \pm 0.47$ & $1.78 \pm 1.23$ & $-0.022(0.682)$ & $-0.282(0.197)$ & 0.1867 \\
\hline NC & 12 & 3 & $0.318 \pm 0.164$ & $1.04 \pm 0.54$ & $1.34 \pm 0.88$ & $-0.051(0.262)$ & $0.269(0.480)$ & 0.4860 \\
\hline TH & 8 & 3 & $0.714 \pm 0.123$ & $2.12 \pm 0.37$ & $1.56 \pm 1.06$ & $0.027(0.971)$ & $-0.800(0.949)$ & 0.1225 \\
\hline TP & 7 & 4 & $0.857 \pm 0.102$ & $6.56 \pm 1.61$ & $6.62 \pm 3.41$ & $-0.063(0.519)$ & $-0.356(0.915)$ & 0.1474 \\
\hline ALS & 4 & 2 & $0.667 \pm 0.204$ & $0.90 \pm 0.28$ & $0.74 \pm 0.74$ & $-0.002(0.883)$ & $0.065(0.852)$ & 0.5556 \\
\hline CT & 3 & 2 & $0.667 \pm 0.314$ & $0.90 \pm 0.42$ & $0.90 \pm 0.90$ & - & - & 0.5556 \\
\hline WC & 4 & 4 & $1.000 \pm 0.177$ & $3.15 \pm 0.82$ & $2.95 \pm 2.01$ & $-0.044(0.806)$ & $0.059(0.067)$ & 0.2222 \\
\hline WH & 6 & 2 & $0.333 \pm 0.215$ & $0.45 \pm 0.29$ & $0.59 \pm 0.59$ & $-0.003(0.240)$ & $0.154(0.568)$ & 0.2222 \\
\hline FKS & 19 & 4 & $0.456 \pm 0.132$ & $1.50 \pm 0.46$ & $1.93 \pm 1.04$ & $-0.035(0.277)$ & $0.150(0.550)$ & 0.3502 \\
\hline HNS & 8 & 2 & $0.571 \pm 0.094$ & $2.32 \pm 0.38$ & $1.56 \pm 1.06$ & $-0.007(0.994)$ & $-0.171(0.985)$ & $0.8367^{*}$ \\
\hline KS & 20 & 11 & $0.916 \pm 0.038$ & $4.11 \pm 0.93$ & $5.33 \pm 2.24$ & $-0.042(0.188)$ & $-0.797(0.045)$ & 0.0680 \\
\hline TN & 3 & 2 & $0.667 \pm 0.314$ & $6.31 \pm 2.97$ & $6.31 \pm 4.23$ & - & - & 1.0000 \\
\hline $\mathrm{CL}$ & 6 & 3 & $0.733 \pm 0.155$ & $6.49 \pm 1.30$ & $5.33 \pm 2.95$ & $-0.015(0.957)$ & $-0.091(0.973)$ & 0.3467 \\
\hline $\mathrm{CP}$ & 13 & 8 & $0.885 \pm 0.070$ & $7.87 \pm 1.06$ & $8.27 \pm 3.56$ & $-0.035(0.406)$ & $-1.884(0.812)$ & 0.1142 \\
\hline $\mathrm{FL}$ & 5 & 4 & $0.900 \pm 0.161$ & $8.38 \pm 1.93$ & $7.78 \pm 1.33$ & $-0.003(0.822)$ & $-0.207(0.792)$ & 0.3300 \\
\hline HKL & 20 & 7 & $0.789 \pm 0.068$ & $5.69 \pm 0.59$ & $5.33 \pm 2.24$ & $-0.037(0.645)$ & $-2.025(0.945)$ & $0.5288^{* *}$ \\
\hline TML & 8 & 4 & $0.750 \pm 0.139$ & $2.22 \pm 0.36$ & $1.56 \pm 1.06$ & $-0.029(0.993)$ & $-1.148(0.724)$ & 0.1263 \\
\hline YF & 8 & 1 & $0.000 \pm 0.000$ & $0.00 \pm 0.00$ & $0.00 \pm 0.00$ & - & - & 0.0000 \\
\hline YL & 10 & 3 & $0.511 \pm 0.164$ & $1.98 \pm 1.13$ & $2.87 \pm 1.57$ & $-0.035(0.113)$ & $0.263(0.796)$ & 0.1669 \\
\hline \multicolumn{9}{|c|}{ Region } \\
\hline NW & 33 & 6 & $0.674 \pm 0.078$ & $2.81 \pm 0.66$ & $4.33 \pm 1.73$ & $-0.094(0.130)$ & $-0.088(0.683)$ & 0.0435 \\
\hline WC & 17 & 9 & $0.890 \pm 0.054$ & $2.60 \pm 0.33$ & $2.40 \pm 1.24$ & $0.000(0.659)$ & $-6.344(0.634)$ & 0.0614 \\
\hline SW & 50 & 15 & $0.871 \pm 0.032$ & $3.11 \pm 0.49$ & $4.83 \pm 1.76$ & $-0.064(0.106)$ & $-1.005(0.012)$ & 0.0448 \\
\hline SE & 70 & 21 & $0.896 \pm 0.019$ & $6.25 \pm 0.36$ & $7.29 \pm 2.32$ & $0.000(0.254)$ & $-6.017(0.606)$ & 0.0553 \\
\hline Total & 170 & 35 & $0.895 \pm 0.015$ & $4.79 \pm 0.31$ & $8.05 \pm 2.22$ & $-0.041(0.062)$ & $-3.496(0.001)$ & 0.0211 \\
\hline
\end{tabular}

Populations and regions are defined in Table 1.

Tajima's $D$ and Fu's $F$ s were estimated based on the coalescent simulations with 1000 replicates in consideration of recombination.

${ }^{*} P<0.05 ;{ }^{*} P<0.00001$ for the raggedness index reject the null hypothesis of expectation under a sudden demographic expansion model.

$N$ is the number of sequences; $H$ is the number of haplotypes; $H d$ is the haplotype diversity; $\pi$ and $\theta$ are the nucleotide diversity estimates. 
Table 3: Pairwise $F_{\mathrm{ST}}$ estimates among the four geographic regions of Cinnamomum kanehirae.

\begin{tabular}{lcccc}
\hline FST & NW & WC & SW & SE \\
\hline NW & - & 0.018 & 0.006 & $\mathbf{0 . 1 7 5 * * *}$ \\
WC & 0.006 & - & 0.032 & $\mathbf{0 . 1 8 7 ^ { * * }}$ \\
SW & 0.016 & 0.012 & - & $\mathbf{0 . 1 8 6 ^ { * * * }}$ \\
SE & $\mathbf{0 . 0 4 7 *}^{*}$ & $\mathbf{0 . 0 4 2 *}^{*}$ & $\mathbf{0 . 0 7 3 ^ { * }}$ & - \\
\hline
\end{tabular}

The bold values indicate comparisons between the SE and other regions.

Above the diagonal: estimates for $L f y$.

Below the diagonal: estimates for $C h s$.

Geographic regions are defined in Figure 1.

Significant $F_{\mathrm{ST}} P$ values: ${ }^{*} P<0.05 ;{ }^{* *} P<0.01 ;{ }^{* *} P<0.00001$.

other, the haplotype diversity and nucleotide diversity of the SE region estimated for Chs were significantly lower than those of the other three regions, but the nucleotide diversity of the SE region estimated for Lfy was significantly higher than those of the other regions. In addition, the haplotype diversity of the NW region estimated for Lfy was significantly lower than that of the SE region (Table 2).

\section{Population structure and gene flow}

Mean population pairwise $F_{\mathrm{ST}}$ values were 0.101 and 0.293 for the Chs and Lfy sequences, respectively (Additional file 2). The haplotype network depicted no clear patterns of population or regional genetic structuring (Additional file 3). Mean $F_{\mathrm{ST}}$ values for regional comparisons were 0.033 and 0.086 for the Chs and Lfy sequences, respectively (Table 3 ). Although the pairwise $F_{\mathrm{ST}}$ estimated from two nuclear DNA sequences showed discrep-

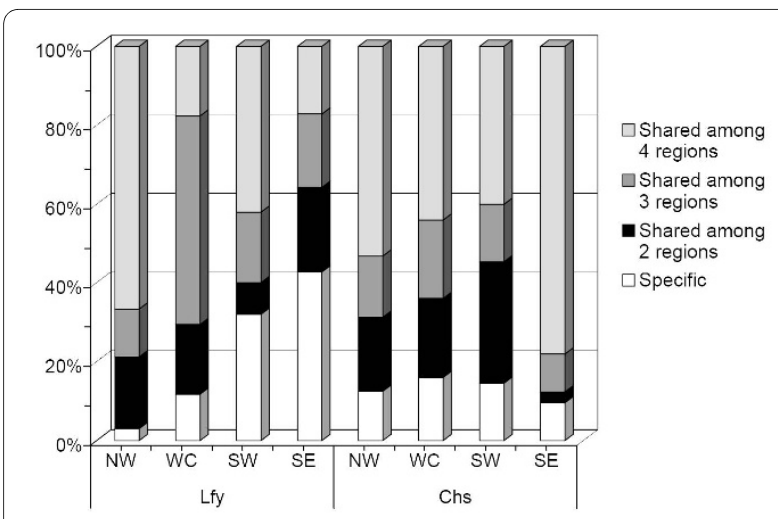

Figure 2 Proportions of common and rare haplotypes of Cinnamomum kanehirae among the four geographic regions. The white bar indicates the proportion of haplotypes that specifically appeared in only one of the four regions; the dark bar is the proportion of haplotypes that also appeared in one of the three other regions; the intermediate-gray bar is the proportion of haplotypes that also appeared in two of the three other regions; and the light-gray bar indicates the proportion of haplotypes that appeared in all four regions. ancies on the levels of genetic differentiation among regional comparisons, both $C h s$ and Lfy pairwise $F_{\mathrm{ST}}$ matrices revealed higher genetic differentiation when $\mathrm{SE}$ was compared to the regions west of the CMR, but lower levels of genetic differentiations were found when only regions west of the CMR were compared (Table 3). The conspicuous level of genetic differentiation between regions on either side of the CMR indicates its barrier effect. A lack of migration-drift equilibrium can be assumed according to the result of the IBD tests (see below). Gene flow ( $\mathrm{Nm}$ ) estimated using Wright's model [51] which assumes migration-drift equilibrium was not appropriate for estimating magnitudes of gene flow. Therefore, gene flow varying over time was assumed when estimating the level of gene flow due to differential levels of common haplotype sharing among regions west of the CMR and across the CMR (Figure 2). We applied the Bayesian approach implemented in MIGRATE [55] to estimate the magnitudes and directions of gene flow between pairs of regional samples. The high number of migrants $(M)$ calculated by the Bayesian approach indicated frequent gene flow, which was not hindered by geological interruption (Figure 1). The Bayesian analysis of

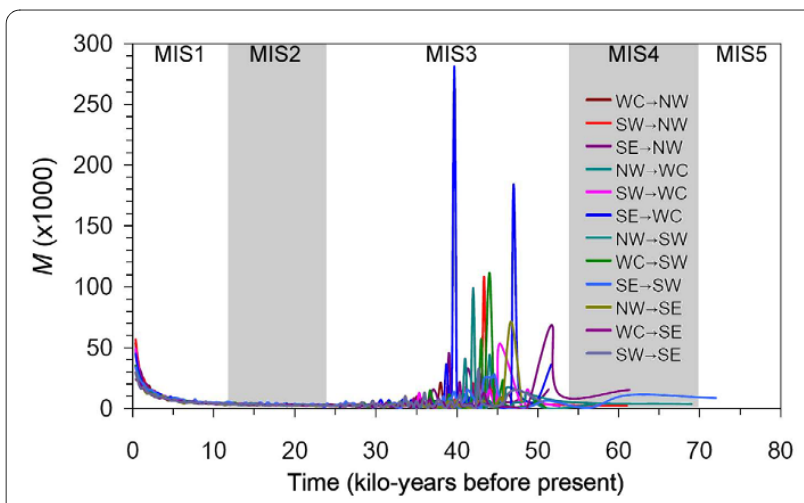

Figure 3 The number of migrants through time. Amplitudes of migrations through time are indicated by the parameter $M$ multiplied by one thousand. 
Table 4: Summary of the analysis of molecular variance (AMOVA). Three comparisons for the AMOVA were made for both Chs and Lfy loci:

\begin{tabular}{|c|c|c|c|c|c|c|}
\hline Source of variation & df & S.S. & Variance component & $\%$ variation & Fixation indices & $P$ value \\
\hline \multicolumn{7}{|l|}{ (1) 4 regions } \\
\hline \multicolumn{7}{|l|}{ Chs } \\
\hline Among regions & 3 & 39.775 & 0.091 & 1.76 & $\Phi_{\mathrm{CT}}=0.01757$ & 0.10362 \\
\hline $\begin{array}{l}\text { Among populations within } \\
\text { regions }\end{array}$ & 15 & 110.731 & 0.255 & 4.92 & $\Phi_{\mathrm{SC}}=0.05010$ & $0.03715^{*}$ \\
\hline Within populations & 191 & 922.56 & 4.83 & 93.32 & $\Phi_{\mathrm{ST}}=0.06679$ & $0.008^{*}$ \\
\hline Total & 209 & 1073.07 & 5.176 & 100 & & \\
\hline \multicolumn{7}{|l|}{ Lfy } \\
\hline Among regions & 3 & 38.162 & 0.181 & 9.07 & $\Phi_{\mathrm{CT}}=0.09071$ & 0.06843 \\
\hline $\begin{array}{l}\text { Among populations within } \\
\text { regions }\end{array}$ & 15 & 74.078 & 0.416 & 20.89 & $\Phi_{\mathrm{SC}}=0.22976$ & $<0.00001^{*}$ \\
\hline Within populations & 151 & 210.737 & 1.396 & 70.04 & $\Phi_{\mathrm{ST}}=0.29963$ & $<0.00001^{*}$ \\
\hline Total & 169 & 322.976 & 1.993 & 100 & & \\
\hline \multicolumn{7}{|l|}{ (2) E and W } \\
\hline \multicolumn{7}{|l|}{ Chs } \\
\hline Among regions & 1 & 29.693 & 0.23 & 4.36 & $\Phi_{C T}=0.04364$ & $0.00978^{*}$ \\
\hline $\begin{array}{l}\text { Among populations within } \\
\text { regions }\end{array}$ & 17 & 120.813 & 0.214 & 4.05 & $\Phi_{\mathrm{SC}}=0.04239$ & $0.04203^{*}$ \\
\hline Within populations & 191 & 922.56 & 4.83 & 91.58 & $\Phi_{S T}=0.08418$ & $0.00489^{*}$ \\
\hline Total & 209 & 1073.067 & 5.274 & 100 & & \\
\hline \multicolumn{7}{|l|}{ Lfy } \\
\hline Among regions & 1 & 35.415 & 0.35925 & 16.95 & $\Phi_{C T}=0.16951$ & $0.01075^{*}$ \\
\hline $\begin{array}{l}\text { Among populations within } \\
\text { regions }\end{array}$ & 17 & 76.824 & 0.36443 & 17.2 & $\Phi_{\mathrm{SC}}=0.20706$ & $<0.00001^{*}$ \\
\hline Within populations & 151 & 210.737 & 1.39561 & 65.85 & $\Phi_{S T}=0.34147$ & $<0.00001^{*}$ \\
\hline Total & 169 & 322.976 & 2.11929 & & & \\
\hline \multicolumn{7}{|l|}{ (3) Three western regions } \\
\hline \multicolumn{7}{|l|}{ Chs } \\
\hline Among regions & 2 & 10.082 & -0.16840 & -2.98 & $\Phi_{\mathrm{CT}}=-0.02983$ & 0.95205 \\
\hline $\begin{array}{l}\text { Among populations within } \\
\text { regions }\end{array}$ & 9 & 90.017 & 0.46911 & 8.31 & $\Phi_{\mathrm{SC}}=0.08068$ & $0.02513^{*}$ \\
\hline Within populations & 125 & 668.178 & 5.34543 & 94.67 & $\Phi_{\mathrm{ST}}=0.05326$ & $0.02811^{*}$ \\
\hline Total & 136 & 768.277 & 5.64613 & & & \\
\hline \multicolumn{7}{|l|}{ Lfy } \\
\hline Among regions & 2 & 2.747 & -0.04460 & -3.91 & $\Phi_{\mathrm{CT}}=-0.3910$ & 0.67097 \\
\hline $\begin{array}{l}\text { Among populations within } \\
\text { regions }\end{array}$ & 9 & 22.460 & 0.19358 & 16.97 & $\Phi_{\mathrm{SC}}=0.16330$ & $<0.00001^{*}$ \\
\hline Within populations & 88 & 87.283 & 0.99186 & 86.94 & $\Phi_{\mathrm{ST}}=0.13058$ & $<0.00001^{*}$ \\
\hline Total & 99 & 112.490 & 1.14083 & & & \\
\hline
\end{tabular}

* Statistically significant $(P<0.05)$

(1) four geographic regions as defined by Lin et al., (2) the eastern (E) and western (W) parts separated by the Central Mountain Range (CMR), and (3) the three geographic regions west of the CMR 
migration showed that the SE region may have served as a dispersal source southwards in recent times (Figure 1).

At the entire population and regional scales, lack of correlations between genetic (FST) and geographic distances (both linear and altitudinal slope) was a common phenomenon according to the Mantel test, and only the SE-SW comparison showed a marginally significant correlation between genetic distance and linear geographic distance $(r=0.314, \mathrm{P}=0.049$ for Chs sequences and $\mathrm{r}=$ $0.295, \mathrm{P}=0.047$ for Lfy sequences, 1000 permutations, one-tailed test). If we consider the altitudinal slope, then the NW-SE and NW-WC comparisons showed significant correlations between genetic and geographic distances for Chs $(\mathrm{r}=0.341, \mathrm{P}=0.011 ; \mathrm{r}=0.427, \mathrm{P}=0.044$, respectively; 1000 permutations, one-tailed test), whereas no significant correlation was found based on Lfy sequences. In addition, we also estimated the most probable time at which gene flow occurred by the Bayesian approach performed using MIGRATE [55], and high probabilities of gene flow were found for each comparison during the last interglacial (Figure 3 ). This result indicates a trend of gene flow that occurred in the recent past or else a large, stable population size of this species in the past.

The AMOVA among the four geographic regions and between the east-west regions had similar results of a high proportion of the overall genetic variation being attributed to within-population levels (Table 4). On average, a relatively low percentage of the total genetic variation was attributable to among-region comparisons for both the four geographic regions and east-west regions. Nevertheless, the level of among-region genetic differentiation was significant when comparing eastern to western populations $\left(\Phi_{\mathrm{CT}}=0.044, P<0.01\right.$ for $C h s$ and $\Phi_{\mathrm{CT}}=$ $0.170, P=0.01$ for $L f y)$. Significant genetic differentiation was also found in both sets of comparisons at the hierarchical level among populations within regions $\left(\Phi_{\mathrm{SC}}=\right.$ 0.050 and $\Phi_{\mathrm{SC}}=0.042$ for $C h s$ and $\Phi_{\mathrm{SC}}=0.230$ and $\Phi_{\mathrm{SC}}=$ 0.207 for $L f y$, respectively, for comparisons of the four geographic regions and the eastern-western regions with $P<0.05)$. Moreover, genetic differentiation among populations was also significant for both sets of comparisons $\left(\Phi_{\mathrm{ST}}=0.067\right.$ and $\Phi_{\mathrm{ST}}=0.084$ for Chs, and $\Phi_{\mathrm{ST}}=0.299$ and $\Phi_{\mathrm{ST}}=0.341$ for $L f y$, respectively for comparisons of the four geographic regions and eastern-western regions with $P<0.01)$. When comparing the three geographic regions west of the CMR, both Chs and $L f y$ revealed no genetic structuring among regions, but a certain level of significant genetic structuring was found at the hierarchical levels among populations within regions and among populations $\left(\Phi_{\mathrm{SC}}=0.080\right.$ and $\Phi_{\mathrm{ST}}=0.053$ for $C h s$, and $\Phi_{\mathrm{SC}}=0.163$ and $\Phi_{\mathrm{ST}}=0.130$ for $L f y$, respectively). Although most comparisons of genetic structure were significant, the relatively shallow genetic structure on average especially when populations west of the CMR were compared represents a scenario of unhindered gene flow incompatible with the rugged geographic topology. The relatively shallow population structure was also supported by the mixed clustering relationships of populations (data not shown) and again reflects the large, contiguous distribution of this species in the past.

\section{Demographic history}

Neutrality tests of Tajima's $D$ revealed non-significant negative values in many individual populations, pooled samples and the four regional samples for both the Chs and Lfy datasets (Table 2). Non-significant negative Fu's $F$ s values were also obtained for all populations, regional samples, and the pooled samples for Chs data. Similar results were also seen for most populations and regional samples with $L f y$ data; however, significant negative Fu's Fs values $(P<0.05)$ in the KS population, SW regions, and pooled samples were found (Table 2). Fu's Fs is considered to be more sensitive in detecting population expansion and suggesting possible past population growth, but the expansion may have been restricted to separate local areas that resulted in the non-significant negative Fu's Fs values for most populations and regions. Moreover, either population reduction, population subdivision, a recent bottleneck, or migration which resulted in secondary contact among previously differentiated lineages could have caused the discrepancy in detecting population expansion using the pooled samples with these two neutrality test statistics $[67,68]$. Non-significant or small negative values of Tajima's $D$ and Fu's Fs were found in many individual populations suggesting stationary in $C$. kanehirae populations. We also calculated the raggedness index under the demographic expansion model for each population and found that many individual populations had a high raggedness index (Table 2). We further analyzed the mismatch distribution under the spatial expansion model considering population subdivision [60-62]. Analysis of the mismatch distribution showed a multimodal pattern characteristic of population differentiation which corresponds to demographic growth and a subsequent bottleneck [[61], data not shown]. It is probable that loss of haplotypes due to the recent bottleneck would have caused the multimodal mismatch distribution. According to the mismatch distribution analysis, the hypothesis of spatial expansion could not be rejected in pooled samples (SSD $=0.021, P=0.502$ for $C h s$ and SSD $=0.011, P=0.38$ for $L f y$, Table 5). A good fit of the spatial expansion was also observed for regional samples according to the non-significant SSD values; however, different expansion times of regional samples estimated by $\tau$ were found due to different coalescent histories of Chs and Lfy sequences (Table 5). The relatively longer expansion time 
Table 5: Estimated spatial expansion parameters for Cinnamomum kanehirae.

\begin{tabular}{|c|c|c|c|c|c|c|}
\hline $\begin{array}{l}\text { Estimated parameters/ } \\
\text { Geographic region }\end{array}$ & NW & WC & SW & SE & Western & Total \\
\hline \multicolumn{7}{|l|}{ Chs } \\
\hline Tau $(95 \%$ Cl) & $\begin{array}{l}25.8 \\
(0.37 \sim 54.22)\end{array}$ & $\begin{array}{l}22.4 \\
(0.75 \sim 131.46)\end{array}$ & $\begin{array}{l}22.1 \\
(0.47 \sim 149.32)\end{array}$ & $\begin{array}{l}5.5 \\
(1.45 \sim 10.04)\end{array}$ & $\begin{array}{l}22.6 \\
(0.62 \sim 143.08)\end{array}$ & $\begin{array}{l}5 \\
(1.22 \sim 14.06)\end{array}$ \\
\hline Theta $(95 \% \mathrm{Cl})$ & $\begin{array}{l}5.19 \\
(0.00072 \sim 10.97)\end{array}$ & $\begin{array}{l}9.00 \\
(0.19 \sim 13.69)\end{array}$ & $\begin{array}{l}9.74 \\
(0.19 \sim 14.97)\end{array}$ & $\begin{array}{l}0.49(0.00072 \sim 2 . \\
12)\end{array}$ & $\begin{array}{l}8.73(0.09066 \sim 13 \\
.99)\end{array}$ & $\begin{array}{l}2.785 \\
(0.00072 \sim 5.71)\end{array}$ \\
\hline Migration rate $(95 \% \mathrm{Cl})$ & $\begin{array}{l}0.89 \\
(0.232 \sim 99999)\end{array}$ & $\begin{array}{l}0.52 \\
(0.384 \sim 99999)\end{array}$ & $\begin{array}{l}0.43 \\
(0.313 \sim 99999)\end{array}$ & $\begin{array}{l}1.65 \\
(0.343 \sim 9.10)\end{array}$ & $\begin{array}{l}0.52 \\
(0.315 \sim 81.79)\end{array}$ & $\begin{array}{l}2.27 \\
(0.572 \sim 16.20)\end{array}$ \\
\hline SSD & 0.0232 & 0.01866 & 0.02165 & 0.06415 & 0.0137 & 0.02117 \\
\hline$P$-value & 0.505 & 0.566 & 0.406 & 0.268 & 0.649 & 0.502 \\
\hline \multicolumn{7}{|l|}{ Lfy } \\
\hline Tau $(95 \%$ Cl) & $\begin{array}{l}8.95 \\
(0.38-9.88)\end{array}$ & $\begin{array}{l}2.10 \\
(0.89-2.93)\end{array}$ & $\begin{array}{l}2.00 \\
(1.11-2.44)\end{array}$ & $\begin{array}{l}2.50 \\
(0.99-11.77)\end{array}$ & $\begin{array}{l}1.40 \\
(0.99-2.65)\end{array}$ & $\begin{array}{l}1.00 \\
(0.52-10.21)\end{array}$ \\
\hline Theta $(95 \% \mathrm{Cl})$ & $\begin{array}{l}2.09 \\
(0.00-2.66)\end{array}$ & $\begin{array}{l}0.00 \\
(0.00-1.20)\end{array}$ & $\begin{array}{l}0.00 \\
(0.00-0.88)\end{array}$ & $\begin{array}{l}4.19 \\
(0.00-8.43)\end{array}$ & $\begin{array}{l}0.44 \\
(0.00-0.98)\end{array}$ & $\begin{array}{l}3.11 \\
(0.00-5.93)\end{array}$ \\
\hline Migration rate $(95 \% \mathrm{Cl})$ & $\begin{array}{l}0.02 \\
(0.48-99999)\end{array}$ & $\begin{array}{l}99999 \\
(7.08-99999)\end{array}$ & $\begin{array}{l}99999 \\
(12.67-99999)\end{array}$ & $\begin{array}{l}8.08 \\
(1.14-168.21)\end{array}$ & $\begin{array}{l}99999 \\
(12.79-99999)\end{array}$ & $\begin{array}{l}74.76 \\
(1.08-99999)\end{array}$ \\
\hline SSD & 0.013 & 0.004 & 0.003 & 0.032 & 0.003 & 0.011 \\
\hline$P$-value & 0.60 & 0.55 & 0.24 & 0.07 & 0.15 & 0.38 \\
\hline
\end{tabular}

Confidence intervals $(\mathrm{Cl}), \mathrm{a}=0.05$.

SSD: sum of squared deviations.

Geographic regions are defined in Figure 1.

Values were obtained from the mismatch distribution under the spatial expansion model.

and smaller migration rate of the NW region for both sequence sets $(\tau=8.95$ and $M=0.02$ for $L f y ; \tau=25.8$ and $M=0.89$ for $C h s$ ) implies a far-distant spatial expansion for older lineages of NW regional samples. In contrast to NW samples, SE regional samples revealed a relatively shorter expansion time and larger migration rate $(\tau=2.50$ and $M=8.08$ for $L f y ; \tau=5.5$ and $M=1.65$ for $C h s$ ), which indicates a recent spatial expansion.

The BSP analysis suggested a past increase in the effective population size of C. kanehirae for both nuclear markers (Figure 4, Additional file 4). An increase in the effective population size inferred by $C h s$ was smaller than that inferred by Lfy. Moreover, the time of population

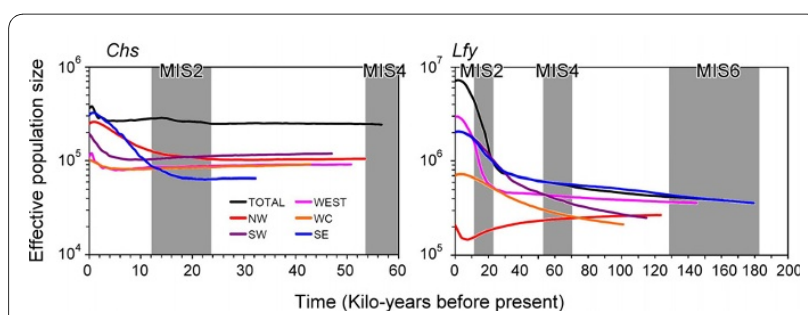

Figure 4 Bayesian skyline plot revealing the demographic trends of $C h s$ and Lfy intron lineages of Cinnamomum kanehirae. The population size was measured as the effective population size per generation. MIS, marine isotope stage. growth inferred by Chs was later than that inferred by Lfy. Slight differences in trends of the population size increase and expansion time are likely due to different coalescent histories of the two loci and uncertainty of molecular dating [69]. On the other hand, a clear recent bottleneck was revealed by the pooled samples of Chs sequences, but $L f y$ data showed only a slight decrease in population size after the last glacial maximum (LGM) expansion. In addition, regional samples of western, WC, and SE revealed a more-obvious population decline for Chs than for $L f y$ (Figure 4). Moreover, NW samples displayed a history of a prolonged population decline followed by a recent sudden expansion based on Lfy variations.

\section{Discussion}

\section{Genetic diversity}

Historical demographic events and population sizes of most natural populations fluctuated and left traces in patterns of their genetic diversity. In this study, C. kanehirae had higher or comparable nucleotide diversities for both Chs and Lfy or either one of them separately compared to the nucleotide diversity in population studies of nuclear genes such as Chs in the Hippophaë rhamnoides species complex [70], the glyceraldehyde-3-phosphate dehydrogenase (G3pdh) gene in Q. glauca [71] and the nucleotide 
diversity of G3pdh in Manihot esculenta [72], the PHYP and PHYO loci in Pinus sylvestris [73], and the fruit vacuolar invertase gene in Solanum pimpinellifolium [74]. Although the comparison of nucleotide diversity using nuclear DNA sequence data might not be complete, the high level of allozyme variation found also suggests a great potential for high genetic variation in nuclear DNA sequences of $C$. kanehirae [35]. High nucleotide diversity of nuclear genes may reflect a long evolutionary history of a large, stable population, or mixing of differential lineages via range expansion [75-77] and is consistent with field surveys of the contiguous range distribution of $C$. kanehirae in the past $[25,26]$.

\section{Historical and recent demography of Cinnamomum kanehirae}

Overall, it can be seen that the demographic history of $C$. kanehirae is far more complex than previously thought, with evidence of historical range expansion and a very recent bottleneck (Table 2, Figure 4). While population expansion was rejected by Tajima's $D$ and Fu's $F$ s test statistics in most population and regional samples, the high raggedness index estimated for individual populations suggests the occurrence of bottleneck events [78]. Population bottlenecks were also evident when analyzed with the BSP (Figure 4). On the other hand, the mismatch analyses failed to reject a spatial expansion model for all datasets including pooled and regional samples (Table 5). Historical spatial expansion was also revealed by the BSP analysis (Figure 4). From these results the demographic history of C. kanehirae conformed to the hypothesis of past spatial range expansion followed by a very recent population bottleneck. However, the past spatial range expansion might not display a molecular signature of a unimodal distribution characteristic of sudden expansions in un-subdivided populations, even though populations had expanded by several orders of magnitude after the past expansion [61] and was evident through analysis with the MIGRATE software, which might reflect a historically large stable population of C. kanehirae (Figure 3 ). The level of nucleotide diversity of $C$. kanehirae might therefore be a species-associated feature, and also a result of its past evolutionary history as well as contemporary events.

The climate during interglacial periods in Taiwan was mostly humid and warm (in contrast to glacial periods) $[79,80]$, and therefore habitats at different elevations were appropriate for the growth of C. kanehirae. Population expansion after the LGM was inferred for several plant species including C. kanehirae based on cpDNA variations $[21,37,40,81]$. Further information on the demographic history of C. kanehirae was revealed by nuclear DNA variations. It is likely that larger genetic variability that accumulated in nuclear markers coalesced into a lon- ger genealogy relative to cpDNA, reflecting greater sensitivity in revealing insights into both recent and older events. Moreover, C. kanehirae is an insect-pollinated hermaphrodite with male and female flowers at different times possibly promoting outcrossing and therefore at least a 2-fold higher effective population size of nuclear loci relative to cpDNA makes it more sensitive to population oscillations. The vegetational history traced by pollen records illustrates rapid growth of Alnus, Liquidambar, Mallotus, Trema, and the Chenopodiaceae in subtropical forests of Taiwan [82]. Characteristics of a slow growth rate and long generation time (approximate 20 years) may be limiting factors in habitat establishment for C. kanehirae when competing with other plant species, which thus reinforced the present-day bottleneck.

Loss of genetic diversity due to anthropogenic factors might not be apparent because of the high genetic diversity that accumulated during past range expansions and resulted in only a slight decline in the recent effective population size as estimated by the BSP analysis. Nevertheless, this small decline in the recent population size reveals a commencing phase of a bottleneck in C. kanehirae inflicted by anthropogenic factors. The past increase in gene flow and spatial expansion should have assisted the dispersal of population- and region-specific haplotypes; however, human interventions including overdeforestation and habitat destruction caused declining of population size and fewer opportunities for colonization of these specific haplotypes.

\section{Contemporary genetic structure and gene flow}

Cinnamomum kanehirae is a plant species with bird-dispersed seeds. Forest birds in the warm period of the last interglacial [83] could have facilitated seed dispersal of Lauraceae species and accelerated gene flow between $C$. kanehirae populations. Cinnamomum kanehirae has a similar pattern of diversity distribution as that of Machilus thunbergii (Lauraceae) based on cpDNA variations with most populations possessing the ancestral haplotype $[40,84]$. A shared ancestral polymorphism was the cause of the lack of genetic differentiation among populations in these species. In this study, relatively low levels of genetic differentiation $\left(F_{\mathrm{ST}}\right)$ and a high degree of gene flow were also found by estimates of $M$ based on nuclear DNA variations. Moreover, the haplotype network depicted no clear patterns of geographic structuring, further supporting the regional migrations of haplotypes (Additional file 3). The overall spatial genetic differentiation estimated among all C. kanehirae populations was not purely stochastic, but instead probably reflects the effect of secondary contacts through migration due to range expansion after the LGM (Figure 3, Table 5).

Rates and patterns of dispersal and migration between populations will affect the genetic structure of species: 
the higher the dispersal ability, the lower the population structuring [85]. The AMOVA revealed a certain level of significant genetic structuring in C. kanehirae populations, but the level of the genetic structuring of the two nuclear DNA loci assayed was relatively low on average at all hierarchical levels. Relatively low levels of genetic differentiation in C. kanehirae, especially among populations west of the CMR (Table 3), can be attributed to two possibilities: first, gene exchange between long-term isolated populations and a second, recent fragmentation of a large population with recurrent gene flow. A similar consequence of a lack of genetic structuring and low population differentiation was observed for these two possibilities; however, there were slight differences in the outcomes. In the situation of long-term isolation, each separate population would have independently experienced genetic drift, and resulted in high frequencies of rare haplotypes in each population [86]. On the other hand, if the populations were recently separated, there would insufficient time for genetic drift to have occurred in each small fragmented population, and most populations would share common haplotypes [87]. Sharing of haplotypes was frequently found among populations and among regions (Table 1, Figure 2), although some haplotypes were region- and/or population-specific, however, with relatively low proportions. Therefore, the hypothesis of recent fragmentation of a large population with recurrent gene flow is highly probable. A general lack of IBD, at a regional scale to the west of the CMR, is typically considered to be the result of a large, stable population with historically recurring gene flow, which was further supported by the high migration rates among both populations and regions (Figure 3).

The implications of incomplete drift-migration equilibrium can further explain the contemporary genetic structure of C. kanehirae, which is the outcome of the interaction between inherent past spatial expansion with the barrier effect of the CMR and recent bottleneck events. Taiwan is a continental island which began to rise approximately 4 Mya by tectonic compression of the Eurasian and Philippine Sea Plates. The CMR geographically separates the landscape into eastern and western parts [13]. The barrier effect of gene flow by the CMR in Taiwan was observed in several plant and animal studies $[37,81,88]$. The AMOVA indicated some level of geographic structuring resulted in haplotypes specific to either the eastern or western populations of C. kanehirae, which might be related to the barrier effect of the CMR, and this was statistically supported (Table 4). The occurrence of population- or region-specific haplotypes may have resulted from a recent bottleneck event due to human interventions that caused the loss of haplotypes in other populations and regions; however, the possible fail- ure to discover haplotypes due to the small sample size cannot be excluded. Historically, recurrent gene flow between populations, across geographic regions and across the CMR possibly diminished the level of genetic differentiation and the influence of the CMR barrier. Therefore, common haplotype distributions between geographic regions and relatively shallow genetic structuring are the result of historical gene flows. Under the drift-migration equilibrium, patterns of exclusivity are not expected, particularly for a large population size or a short isolation time. In this scenario, common haplotypes should be more abundant than private ones in an individual population. However, rare or population-specific haplotypes occurred in almost all of the populations examined (Table 1).

\section{Dispersal after the LGM}

Historical and extrinsic ecological events can leave signatures in the spatial genetic structure of a species and provide insights into understanding the species' evolutionary history [75]. In Taiwan, six subtropical tree species have been phylogeographically studied using cpDNA variations, and the SE part of Taiwan was inferred to be a major diversity center based on average $F_{\mathrm{ST}}$ divergences from populations of other regions [22,37,40,71,81,84,89], and that was further suggested by this study because a higher average $F_{\mathrm{ST}}$ divergence from other regions was found when the SE was compared to other regions (Table 3). However, the SE region being postulated as a diversity center in this way may only reflect its long isolation from other regions, which was suggested by the high level of regional-specific haplotypes and very recent expansion southward. In contrast, the southerly expansion event of the NW region to the west of the CMR was older according to the TMRCA estimates (Table 5). The trend of a temperature rise after cold climatic periods of the Pleistocene was inferred to have occurred from south to north assisted by the warm Kuroshio Current that flow northward offshore of the east coast of Taiwan [90]. Although the South China Sea Warm Current flowed through the Taiwan Strait after the LGM when sea levels again rose, the magnitude of the temperature rise might not have been significant, as the area west of the CMR faces cold fronts from the north as well as the barrier effect of the CMR in receiving warm temperatures from the south carried by the Kuroshio Current. Thus, a deferred timing of the temperature rise may have occurred in western populations of C. kanehirae (except populations in the SW region). The onset of a temperature rise after the LGM for populations located in the SE region preceded that of populations located in other regions, thereby facilitating the migration from SE to SW regions by C. kanehirae. 


\section{Conclusions}

Distributions of genetic variations in wild populations provide insights into a species' evolutionary history and its future continuity [75,91]. Cinnamomum kanehirae is confronted with conditions of being rare, fragmented, and threatened at the present time, consistent with the genetic survey that revealed a pattern of population growth followed by an ongoing bottleneck. Despite the declining effective population size of $C$. kanehirae, the genetic diversity of remnant individuals showed no dramatic reduction in genetic diversity. In C. kanehirae, a tree with a long generation time, the rapid population decline probably began decades ago due to anthropogenic interventions for two or more generations. Thus information on the loss of genetic diversity might not be spontaneously revealed, but will probably be seen within two or more generations if the populations are not restored. In light of the declining effective population size, the condition of the true population size of $C$. kanehirae at present may be far more severely threatened. In addition to the continuing illegal selective cutting for cultivating the medicinal fungus, A. cinnamomea, the loss of habitat is another serious issue contributing to population declines of C. kanehirae. Elevations where C. kanehirae grows range $200 \sim 2000 \mathrm{~m}$, and overdevelopment for farming vegetables, tea, and fruit crops has destroyed the natural habitats of primeval forests, including habitats of C. kanehirae. Therefore, loss of the population size of C. kanehirae was mainly caused by human overexploitation. In consequence, it is essential that this valuable species be conserved through habitat restoration, which can advance the restoration of the effective population size of C. kanehirae. Further field surveys to locate plants and grafts for ex situ conservation are another requirement to conserve this species. Management strategies should also consider reinforcing local populations with individuals originating from populations showing the closest genetic relatedness to produce larger population with higher genetic variability. In summary, conservation strategies must therefore aim for habitat restoration and remnant diversity preservation, and avoid the occurrence of genetic inbreeding in populations of $C$. kanehirae.

\section{Additional material}

Additional file 1 Polymorphic sites among haplotypes at Chs and Lfy. The table provides polymorphic information for both the Chs and Lfy loci for each haplotype.

Additional file 2 Pairwise $F_{S T}$ of 19 Cinnamomum kanehirae populations. The table provides the pairwise genetic distance matrix obtained using Chs and Lfy DNA.
Additional file 3 Phylogenetic network constructed by both Chs and Lfy sequences. The figure shows the haplotype networks constructed using a statistical parsimony approach. The long-fragment indel of Chs sequences was treated as one-mutation step and recoded. The limit of 90\% connection was used to estimate the network. Four geographic regions were indicated proportionally with four colors.

Additional file $\mathbf{4}$ Changes in effective population size in regional and pooled samples of Cinnamomum kanehirae. The figure shows the effective population size per generation for regional and pooled samples of Cinnamomum kanehirae based on Chs and Lfy datasets. The solid line represents mean values of the estimated effective population size with lower (0.05) and upper (0.95) bounds.

\section{Authors' contributions}

SYH and TPL conceived the research; DCK, CCL, and $\mathrm{KCH}$ collected the data; $\mathrm{PCL}$ analyzed the data and wrote the first draft; $\mathrm{SYH}$ led the writing. All authors read and approved the final manuscript.

\section{Acknowledgements}

This investigation was funded by the Council of Agriculture (grant no. 96AS7.2.2-FB-e2), Executive Yuan, Taiwan to Shih-Ying Hwang. The authors acknowledge the assistance of the Taiwan Forestry Research Institute in providing the materials of Cinnamomum kanehirae growing in a scion garden at the Liukuei Research Center, Kaohsiung, Taiwan.

\section{Author Details}

1Department of Life Science, Pingtung University of Science and Technology, Pingtung 91201, Taiwan, ${ }^{2}$ Institute of Plant Biology, National Taiwan University, Taipei 10617, Taiwan, ${ }^{3}$ Department of Life Science, National Taiwan Normal University, Taipei, 11677, Taiwan and 4Department of Life Sciences, National Taiwan University, Taipei 10617, Taiwan

Received: 10 July 2009 Accepted: 30 April 2010 Published: 30 April 2010

\section{References}

1. Hewitt GM: Some genetic consequences of ice ages, and their role in divergence and speciation. Biol J Linn Soc Lond 1996, 58:247-276.

2. Hewitt G: The genetic legacy of the Quaternary ice ages. Nature 2000, 405:907-913.

3. Lee-Yaw JA, Irwin JT, Green DM: Postglacial range expansion from northern refugia by the wood frog, Rana sylvatica. Mol Ecol 2008, 17:867-884

4. Depraz A, Cordellier M, Hausser J, Pfenninger M: Postglacial recolonization at a snail's pace (Trochulus villosus): confronting competing refugia hypotheses using model selection. Mol Ecol 2008, 17:2449-2462

5. Schmitt T, Haubrich $\mathrm{K}$ : The genetic structure of the mountain forest butterfly Erebia euryale unravels the late Pleistocene and postglacial history of the mountain coniferous forest biome in Europe. Mol Ecol 2008, 17:2194-2207.

6. Puscas M, Choler P, Tribsch A, Gielly L, Rioux D, Gaudeul M, Taberlet P: Post-glacial history of the dominant alpine sedge Carex curvula in the European Alpine System inferred from nuclear and chloroplast markers. Mol Ecol 2008, 17:2417-2429.

7. Ikeda H, Senni K, Fujii N, Setoguchi H: Consistent geographic structure among multiple nuclear sequences and cpDNA polymorphisms of Cardamine nipponica Franch. et Savat. (Brassicaceae). Mol Ecol 2008, 17:3178-3188

8. Beck JB, Schmuths H, Schaal BA: Native range genetic variation in Arabidopsis thaliana is strongly geographically structured and reflects Pleistocene glacial dynamics. Mol Ecol 2008, 17:902-915.

9. Su YC, Chang YH, Lee SC, Tso IM: Phylogeography of the giant wood spider (Nephila pilipes, Araneae) from Asian-Australian regions. J Biogeogr 2007, 34:177-191.

10. Yasuda SP, Vogel P, Tsuchiya K, Han SH, Lin LK, Suzuki H: Phylogeographic patterning of mtDNA in the widely distributed harvest mouse (Micromys minutus) suggests dramatic cycles of range contraction and expansion during the mid- to late Pleistocene. Can J Zoo/ 2005, 83:1411-1420. 
11. Brubaker LB, Anderson PM, Edwards ME, Lozhkin AV: Beringia as a glacial refugium for boreal trees and shrubs: new perspectives from mapped pollen data. J Biogeogr 2005, 32:833-848.

12. Bird MI, Taylor D, Hunt C: Environments of insular Southeast Asia during the Last Glacial Period: a savanna corridor in Sundaland? Quat Sci Rev 2005, 24:2228-2242

13. Shen CF: The biogeography of Taiwan: 2 . Some preliminary thoughts and studies. National Taiwan Museum Annual Report 1997, 40:361-450.

14. Siame L, Chu HT, Carcaillet J, Bourles D, Braucher R, Lu WC, Angelier J, Dussouliez P: Glacial retreat history of Nanhuta Shan (north-east Taiwan) from preserved glacial features: the cosmic ray exposure perspective. Quat Sci Rev 2007, 26:2185-2200.

15. Böse M: Traces of glaciation in the high mountains of Taiwan. In Quaternary glaciations-extent and chronology Part III: Asia, Latin America, Africa, Australasia, Antarctica Edited by: Ehlers J, Gibbard PL. Amsterdam: Elsevier; 2004:347-352

16. Hsieh CF: Composition, endemism and phytogeographical affinities of the Taiwan flora. Taiwania 2002, 47:298-310.

17. Hebenstreit R, Bose M, Murray A: Late Pleistocene and early Holocene glaciations in Taiwanese mountains. Quat Int 2006, 147:76-88.

18. Ono YG, Aoki T, Hasegawa H, Liu DL: Mountain glaciation in Japan and Taiwan at the global last glacial maximum. Quat Int 2005, 138:79-92.

19. Liew PM, Huang SY, Kuo CM: Pollen stratigraphy, vegetation and environment of the last glacial and Holocene - a record from Toushe Basin, central Taiwan. Quat Int 2006, 147:16-33.

20. Lin TP: Allozyme variations in Michelia formosana (Kanehira) Masamune (Magnoliaceae), and the inference of a glacial refugium in Taiwan. Theo App/ Genet 2001, 102:450-457.

21. Hwang SY, Lin TP, Ma CS, Lin CL, Chung JD, Yang JC: Postglacial population growth of Cunninghamia konishii (Cupressaceae) inferred from phylogeographical and mismatch analysis of chloroplast DNA variation. Mol Ecol 2003, 12:2689-2695.

22. Lee YJ, Hwang SY, Ho KC, Lin TP: Source populations of Quercus glauca in the last glacial age in Taiwan revealed by nuclear microsatellite markers. J Hered 2006, 97:261-269.

23. Chanderbali AS, Werff H van der, Renner SS: Phylogeny and historical biogeography of Lauraceae: evidence from the chloroplast and nuclear genomes. Annals of the Missouri Botanical Garden 2001 88:104-134

24. Liao JC: Lauraceae. In Flora of Taiwan Volume 2. 2nd edition. Edited by: Boufford DE, Hsieh C-F, Huang T-C, Ohashi H, Yang Y-P, Lu S-Y. Taipei, Taiwan: Editorial Committee of Flora of Taiwan; 1996:433-499.

25. Lin TP: Cinnamomum kanehirae Hay. and Cinnamomum micranthum (Hay.) Hay. Bulletin of Taiwan Forest Research Institute 1993, 8:11-20.

26. Uka S: Report on the survey of Taiwan camphora trees Taipei: Monopoly Bureau, Formosan Government; 1927.

27. Chang TT, Chou WN: Antrodia cinnamomea sp. nov. on Cinnamomum kanehirai in Taiwan. Mycol Res 1995, 99:756-758.

28. Chang TT, Chou WN: Antrodia cinnamomea reconsidered and $A$ salmonea sp. nov. on Cunninghamia konishii in Taiwan. Bot Bull Acad Sin 2004, 45:347-352

29. Wu SH, Ryvarden L, Chang TT: Antrodia camphorata ("niu-chang-chih"), new combination of a medicinal fungus in Taiwan. Bot Bull Acad Sin 1997, 38:273-275.

30. Song TY, Yen GC: Antioxidant properties of Antrodia camphorata in submerged culture. J Agric Food Chem 2002, 50:3322-3327.

31. Yang HL, Hseu YC, Chen JY, Yech YJ, Lu FJ, Wang HH, Lint PS, Wang BC: Antrodia camphorata in submerged culture protects low density lipoproteins against oxidative modification. Am J Chin Med 2006, 34:217-231.

32. Hseu YC, Chang WC, Hseu YT, Lee CY, Yech YJ, Chen PC, Chen JY, Yang HL: Protection of oxidative damage by aqueous extract from Antrodia camphorata mycelia in normal human erythrocytes. Life Sci 2002, 71:469-482.

33. Chen $\mathrm{CH}$, Yang SW, Shen YC: New steroid acids from Antrodia cinnamomea, a fungal parasite of Cinnamomum micranthum. J Nat Prod 1995, 58:1655-1661.

34. Lee $\mathrm{H}$, Huang RL, Chen CT, Chen HC, Hsu WC, Lu MK: Antrodia camphorata polysaccharides exhibit anti-hepatitis B virus effects. FEMS Microbiol Lett 2002, 209:63-67.

35. Lin TP, Cheng YP, Huang SG: Allozyme variation in four geographic areas of Cinnamomum kanehirae. J Hered 1997, 88:433-438.
36. Chung JD, Lin TP, Tan YC, Lin MY, Hwang SY: Genetic diversity and biogeography of Cunninghamia konishii (Cupressaceae), an island species in Taiwan: a comparison with Cunninghamia lanceolata, a mainland species in China. Mol Phylogenet Evol 2004, 33:791-801.

37. Cheng YP, Hwang SY, Lin TP: Potential refugia in Taiwan revealed by the phylogeographical study of Castanopsis carlesii Hayata (Fagaceae). Mol Ecol 2005, 14:2075-2085.

38. Drummond AJ, Rambaut A, Shapiro B, Pybus OG: Bayesian coalescent inference of past population dynamics from molecular sequences. $\mathrm{Mol}$ Biol Evol 2005, 22:1185-1192.

39. Broughton RE, Harrison RG: Nuclear gene genealogies reveal historical, demographic and selective factors associated with speciation in field crickets. Genetics 2003, 163:1389-1401.

40. Kuo DC, Lin CC, Ho KC, Cheng YP, Hwang SY, Lin TP: Two genetic divergence centres revealed by chloroplastic DNA variation in populations of Cinnamomum kanehirae Hay. Conservation Genetic 2009. doi: 10.1007/s10592-10009-19901-10595

41. Doyle JJ, Doyle JL: Isolation of plant DNA from fresh tissue. Focus 1990, 12:13-15.

42. Strand AE, LeebensMack J, Milligan BG: Nuclear DNA-based markers for plant evolutionary biology. Mol Ecol 1997, 6:113-118.

43. Frohlich MW, Meyerowitz EM: The search for flower homeotic gene homologs in basal angiosperms and gnetales: a potential new source of data on the evolutionary origin of flowers. Int J Plant Sci 1997, 158:S131-S142.

44. Clark AG: Inference of haplotypes from PCR-amplified samples of diploid populations. Mol Biol Evol 1990, 7:111-122.

45. Okuyama Y, Fujii N, Wakabayashi M, Kawakita A, Ito M, Watanabe M, Murakami N, Kato M: Nonuniform concerted evolution and chloroplast capture: heterogeneity of observed introgression patterns in three molecular data partition phylogenies of Asian Mitella (Saxifragaceae). Mol Biol Evol 2005, 22:285-296.

46. Thompson JD, Gibson TJ, Plewniak F, Jeanmougin F, Higgins DG: The CLUSTAL_X windows interface: flexible strategies for multiple sequence alignment aided by quality analysis tools. Nucleic Acids Res 1997, 25:4876-4882

47. Hall TA: BioEdit: a user-friendly biological sequence alignment editor and analysis program for Windows 95/98/NT. Nucl Acids Symposium Series 1999, 41:95-98.

48. Librado P, Rozas J: DnaSP v5: a software for comprehensive analysis of DNA polymorphism data. Bioinformatics 2009, 25:1451-1452.

49. Clement M, Posada D, Crandall KA: TCS, a computer program to estimate gene genealogies. Mol Ecol 2000, 9:1657-1659.

50. Excoffier L, Laval G, Schneider S: Arlequin (version 3.0): An integrated software package for population genetics data analysis. Evol Bioinform Online 2005, 1:47-50

51. Wright S: The genetical structure of populations. Ann Eugen 1951, 15:323-354

52. Hellberg ME: Relationships between inferred levels of gene flow and geographic distance in a philopatric coral, Balanophyllia elegans. Evolution 1994, 48:1829-1854.

53. Jensen $J$, Bohonak AJ, Kelley ST: Isolation by distance, web service. BMC Genetics 2005, 6:13.

54. Wall JD: Estimating ancestral population sizes and divergence times. Genetics 2003, 163:395-404

55. Beerli P: Migrate version 3.0 - a maximum likelihood and Bayesian estimator of gene flow using the coalescent. 2008 [http:// popgen.sc.fsu.edu/Migrate-n.html].

56. Tajima F: Statistical method for testing the neutral mutation hypothesis by DNA polymorphism. Genetics 1989, 123:585-595.

57. Fu YX: Statistical tests of neutrality of mutations against population growth, hitchhiking and background selection. Genetics 1997, 147:915-925

58. Harpending HC: Signature of ancient population growth in a lowresolution mitochondrial DNA mismatch distribution. Hum Biol 1994, 66:591-600

59. Harpending HC, Sherry ST, Rogers AR, Stoneking M: The genetic structure of ancient human populations. Curr Anthropol 1993, 34:483-496.

60. Excoffier $L$ : Patterns of DNA sequence diversity and genetic structure after a range expansion: lessons from the infinite-island model. $\mathrm{Mol}$ Ecol 2004, 13:853-864 
61. Ray N, Currat M, Excoffier L: Intra-deme molecular diversity in spatially expanding populations. Mol Biol Evol 2003, 20:76-86.

62. Schneider S, Excoffier L: Estimation of past demographic parameters from the distribution of pairwise differences when the mutation rates very among sites: application to human mitochondrial DNA. Genetics 1999, 152:1079-1089.

63. Hamilton G, Currat M, Ray N, Heckel G, Beaumont M, Excoffier L: Bayesian estimation of recent migration rates after a spatial expansion. Genetics 2005, 170:409-417.

64. Koch MA, Haubold B, Mitchell-Olds T: Comparative evolutionary analysis of chalcone synthase and alcohol dehydrogenase loci in Arabidopsis, Arabis, and related genera (Brassicaceae). Mol Biol Evol 2000 17:1483-1498.

65. Drummond AJ, Rambaut A: BEAST: Bayesian evolutionary analysis by sampling trees. BMC Evol Biol 2007, 7:214

66. Rambaut A, Drummond AJ: Tracer v1.4. 2007 [http://beast.bio.ed.ac.uk/ Tracer].

67. Maruyama T, Fuerst PA: Population bottlenecks and non-equilibrium models in population genetics. I. Allele numbers when populations evolve from zero variability. Genetics 1984, 108:745-763.

68. Maruyama T, Fuerst PA: Population bottlenecks and non-equilibrium models in population genetics. II. Number of alleles in a small population that was formed by a recent bottleneck. Genetics 1985, 111:675-689.

69. Ho SY, Saarma U, Barnett R, Haile J, Shapiro B: The effect of inappropriate calibration: three case studies in molecular ecology. PLOS ONE 2008, 3:e1615.

70. Bartish IV, Kadereit JW, Comes HP: Late Quaternary history of Hippophae rhamnoides L. (Elaeagnaceae) inferred from chalcone synthase intron (Chsi) sequences and chloroplast DNA variation. Mol Ecol 2006, 15:4065-4083

71. Shih FL, Cheng YP, Hwang SY, Lin TP: Partial concordance between nuclear and organelle DNA in revealing the genetic divergence among Quercus glauca (Fagaceae) populations in Taiwan. Int J Plant Sci 2006, 167:863-872.

72. Olsen KM: Population history of Manihot esculenta (Euphorbiaceae) inferred from nuclear DNA sequences. Mol Ecol 2002, 11:901-911.

73. García-Gil MR, Mikkonen M, Savolainen O: Nucleotide diversity at two phytochrome loci along a latitudinal cline in Pinus sylvestris. Mol Ecol 2003, 12:1195-1206.

74. Caicedo AL, Schaal BA: Population structure and phylogeography of Solanum pimpinellifolium inferred from a nuclear gene. Mol Ecol 2004 13:1871-1882

75. Frankham R: Relationship of genetic variation to population size in wildlife. Conser Biol 1996, 10:1500-1508.

76. Grant WS, Bowen BW: Shallow population histories in deep evolutionary lineages of marine fishes: insights from sardines and anchovies and lessons for conservation. J Hered 1998, 89:415-426.

77. Avise JC: Phylogeography: The History and Formation of Species Cambridge, MA.: Harvard University Press; 2000.

78. Rogers AR, Harpending H: Population growth makes waves in the distribution of pairwise genetic differences. Mol Biol Evol 1992, 9:552-569.

79. Wei KY: Environmental changes during the late quaternary in Taiwan and adjacent seas: an overview of recent results of the past decade (1990-2000). West Pac Earth Sci 2002, 2:149-160.

80. Liew PM, Kuo CM, Huang SY, Tseng MH: Vegetation change and terrestrial carbon storage of eastern Asia during the last glacial maximum as indicated by new pollen records of northern Taiwan. Glob Planet Change 1998, 16:85-94.

81. Huang SSF, Hwang SY, Lin TP: Spatial pattern of chloroplast DNA variation of Cyclobalanopsis glauca in Taiwan and east Asia. Mol Ecol 2002, 11:2349-2358

82. Tsukada M: Late Pleistocene vegetation and climate in Taiwan (Formosa). PNAS 1966, 55:543-548.

83. Rhymer JM, MCAuley DG, Ziel HL: Phylogeography of the American woodcock (Scolopax minor): Are management units based on band recovery data reflected in genetically based management units? Auk 2005, 122:1149-1160.

84. Wu SH, Hwang CY, Lin TP, Chung JD, Cheng YP, Hwang SY: Contrasting phylogeographical patterns of two closely related species, Machilus thunbergii and Machilus kusanoi (Lauraceae), in Taiwan. J Biogeogr 2006, 33:936-947.

85. Clegg SM, Degnan SM, Kikkawa J, Moritz C, Estoup A, Owens IPF: Genetic consequences of sequential founder events by an island-colonizing bird. PNAS 2002, 99:8127-8132.

86. Kimura M, Clegg SM, Lovette IJ, Holder KR, Girman DJ, Mila B, Wade P, Smith TB: Phylogeographical approaches to assessing demographic connectivity between breeding and overwintering regions in a Nearctic-Neotropical warbler (Wilsonia pusilla). Mol Ecol 2002, 11:1605-1616

87. Printzen C, Ekman S, Tonsberg T: Phylogeography of Cavernularia hultenii: evidence of slow genetic drift in a widely disjunct lichen. Mol Ecol 2003, 12:1473-1486.

88. Toda M, Nishida M, Matsui M, Lue KY, Ota H: Genetic variation in the Indian rice frog, Rana limnocharis (Amphibia: Anura), in Taiwan, as revealed by allozyme data. Herpetologica 1998, 54:73-82.

89. Huang SF, Hwang SY, Wang JC, Lin TP: Phylogeography of Trochodendron aralioides (Trochodendraceae) in Taiwan and its adjacent areas. J Biogeogr 2004, 31:1251-1259.

90. Chen MP, Huang CK, Lo L, Wang CH: Late Pleistocene paleoceanography of the Kurosio Current in the area offshore southeast Taiwan. Terr Atm Ocean Sci 1992, 3:81-110.

91. Raybould AF, Clarke RT, Bond JM, Welters RE, Gliddon CJ: Inferring patterns of dispersal from allele frequency data. In Dispersal Ecology Edited by: Bullock JM, Kenward RE, Hails RS. Oxford: Blackwell Science; 2002:89-110.

doi: 10.1186/1471-2148-10-124

Cite this article as: Liao et al., Historical spatial range expansion and a very recent bottleneck of Cinnamomum kanehirae Hay. (Lauraceae) in Taiwan inferred from nuclear genes BMC Evolutionary Biology 2010, 10:124

\section{Submit your next manuscript to BioMed Central and take full advantage of:}

- Convenient online submission

- Thorough peer review

- No space constraints or color figure charges

- Immediate publication on acceptance

- Inclusion in PubMed, CAS, Scopus and Google Scholar

- Research which is freely available for redistribution 